\title{
Development of Rat Cerebellar Purkinje Cells: Electrophysiological Properties Following Acute Isolation and in Long-Term Culture
}

\author{
Philip E. Hockberger, Hsiu-Yu Tseng, and John A. Connor \\ Department of Molecular Biophysics, AT\&T Bell Laboratories, Murray Hill, New Jersey 07974
}

The objectives of this study were 2-fold: (1) to characterize the electrical properties of Purkinje cells (PCs) acutely isolated from rat cerebella at different stages of development, and (2) to. compare these properties with those recorded from PCs grown in long-term culture. PCs under both conditions were identified with the aid of cell-specific immunocytochemical staining, and the electrical properties were analyzed using whole-cell-recording techniques. PCs acutely isolated during late embryonic and early postnatal periods displayed a progressive change in electrical properties. Between embryonic days 20 and 22 (stage 1), PCs were inexcitable, did not respond to glutamate, and displayed only small outward currents under voltage clamp. During postnatal days 1-4 (stage 2), current stimulation elicited nonovershooting action potentials, and small inward and outward currents were evoked under voltage clamp. Glutamate application depolarized the cells resulting in an increase in intracellular free calcium measured with fura-2. Stage 3 and 4 cells spanned postnatal days 5-9 and 10-14, respectively, and the cells showed progressively larger voltage-dependent conductances and greater sensitivity to glutamate. We found no evidence for either spontaneous or complex spikes in PCs isolated at any of these stages.

In agreement with previous studies, we found that PCs dissociated from postnatal rats did not survive well in culture. On the other hand, PCs from embryonic rats cultured for 2-3 weeks in high-potassium, serum-supplemented medium developed extensive dendritic processes and excitability. Current stimulation or glutamate application elicited depolarizing waveforms reminiscent of climbing fiber-evoked responses in vivo. The results suggest that dendritic processes are important in the generation of complex spikes and that PC excitability can develop in the absence of the highly structured architecture of the intact cerebellum.

Cerebellar Purkinje cells (PCs) were among the first neurons to be identified within the vertcbrate CNS (Purkinje, 1838; Ramón y Cajal, 1890). PCs have subsequently been found in the cerebella of all vertebrate species and are characterized by an ex-

\footnotetext{
Received May 5, 1988; revised Nov. 4, 1988; accepted Dec. 19, 1988.

We wish to thank Drs. Angus Nairn and Paul Greengard of the Rockefeller University for supplying the G-kinase antibodies, and Dr. James Morgan of the Roche Institute of Molecular Biology for supplying the PEP antibodies. That part of this work not sponsored by AT\&T Bell Laboratories was supported by a grant from the Air Force Office of Scientific Research under contract F49620.

Correspondence should be addressed to Dr. Philip E. Hockberger at his present address: Department of Physiology, Northwestern University Medical School, 303 E. Chicago Ave., Chicago, IL 60611.
}

Copyright (C) 1989 Society for Neuroscience $0270-6474 / 89 / 072258-14 \$ 02.00 / 0$ tensive dendritic arborization with a planar geometry (Llinás, 1969; Ito, 1984). There are several stages in the development of this characteristic morphology as the cell differentiates from a round neuroblast to an adult neuron. In the rat these changes occur during late embryonic and early postnatal periods (Addison, 1911; Altman, 1972, 1982). Electrophysiological correlates of these changes in vivo have been restricted to extracellular recordings (Woodward et al., 1969, 1971; Crepel, 1972; Crepel et al., 1976; Shimono et al., 1976). A more detailed analysis has not been possible because the cells are small during development and therefore inaccessible to intracellular recording techniques.

An alternative strategy had been to analyze PC development in culture. Culture conditions afford greater accessibility to cells for microscopic examination and electrophysiological measurements, as well as enabling better control over the extracellular environment. Despite these advantages, several technical obstacles arise when using cultured cells. Two of the more serious concerns have been how to identify specific cell types in cultures and how to establish culture conditions that facilitate cell survival and differentiation. Most investigators have opted to grow PCs in explant cultures where the tissue geometry is minimally disturbed. This offers a more biological microenvironment while facilitating PC identification. In explant cultures PCs have been shown to differentiate morphologically and to develop electrical excitability (Bornstein and Murray 1958; Hild and Tasaki, 1962; Wolf, 1964, 1970; Allerand, 1971; Seil, 1972; Leiman and Seil, 1973; Calvet, 1974; Geller and Woodward, 1974; Gahwiler, 1976; Hendelman and Aggerwal, 1980; Marshall et al., 1980; Moonen et al., 1982; Gruol, 1983). Recently Gruol and Franklin (1987) have shown that PCs grown in explant cultures display simple and complex firing patterns, properties displayed by adult PCs in vivo.

Several groups have attempted to culture PCs following complete tissue dissociation in order to study these cells under more isolated conditions. Cell survival under such conditions, however, is more difficult than with explant cultures (see Messer et al., 1984). Moreover the identification of dissociated cells using solely morphological criteria does not allow one to distinguish between PCs and other macroneurons of the cerebellum, e.g., Golgi cells or deep nuclei cells (see Lasher and Zagon, 1972; Nelson and Peacock, 1973). Recently, immunocytochemical staining techniques have been used for identifying PCs cultured following tissue dissociation (Fields et al., 1982; Weber and Schachner, 1984; Hirano and Ohmori, 1986). Fields et al. (1982) and Weber and Schachner (1984) found that PCs dissociated from embryonic cerebella survived and differentiated better in culture than PCs dissociated from postnatal animals. Hirano and Ohmori (1986) found that embryonic PCs also developed electrical excitability in dissociated cultures. While these results 
signify important progress in cell culture strategies, it is still unclear whether PC differentiation in dissociated cultures parallels events in vivo, and whether the degree of tissue organization affects normal electrophysiological differentiation.

In order to address these points, we have examined the electrophysiological and biophysical properties of PCs acutely isolated from cerebella at various stages of development, and we have compared their properties with those recorded from PCs in long-term culture. Cells were identified under either condition using morphological criteria deduced from immunocytochemical staining for PC-specific antigens. Our intracellular and voltage clamp measurements of acutely isolated cells support and extend the extracellular studies of Woodward et al. $(1969,1971)$ which showed that PC excitability and glutamate sensitivity begin around birth and continue to develop during the following 2-3 weeks. Our results also support the observations of Fields et al. (1982) and Weber and Schachner (1984) which showed that embryonic PCs survived and differentiated better in culture than postnatal cells. Furthermore, we found that embryonic PCs cultured for 2-3 weeks in high potassium medium displayed complex waveforms reminiscent of climbing fiber-like responses in vivo. In the following article (Hockberger et al., 1989) we show that cultured PCs also displayed dendritic localization of their calcium responses, a feature shared by PCs in cerebellar slices. These results indicate that several characteristics of the mature PCs can develop in the absence of the highly stereotyped architecture of the intact cerebellum.

A preliminary report of these findings has been previously presented (Hockberger et al., 1987b).

\section{Materials and Methods}

Tissue dissociation and culture. Cerebella from Sprague-Dawley rats (CAMM, Wayne, $\mathrm{NJ}$ ) were removed at regular intervals between embryonic day 20 (E20) and postnatal day 14 (P14). For embryonic tissue, timed-pregnant adults were anesthetized using ether and fetuses were removed by caesarean section. Cerebella from littermates of the same age were pooled and minced into $0.5-1 \mathrm{~mm}$ pieces while bathed in an antibiotic-isotonic buffer solution at $4^{\circ} \mathrm{C}$. For explant experiments the pieces were cultured as described previously (Hockberger et al., 1987a). For dissociation experiments the pieces were added to $10 \mathrm{ml}$ of antibiotic-isotonic solution containing $0.05 \%$ trypsin $(2 \times$ crystallized; Worthington, Malvern, PA), and incubated in a shaker waterbath at $37^{\circ} \mathrm{C}$ for $2 \mathrm{~min}$. Afterwards the solution was supplemented with $0.8 \mathrm{ml}$ of $0.025 \%$ DNAse (Worthington) and reincubated at $37^{\circ} \mathrm{C}$ for an additional $5 \mathrm{~min}$. The supernatant was then transferred to a trypsin inhibitor solution, containing $20 \mathrm{ml}$ growth medium (without serum; see below) with $2 \mathrm{ml}$ of $2.5 \%$ trypsin inhibitor (Sigma, St. Louis, MO), at room temperature. The remaining portion, which contained the tissue fragments, was replenished with trypsin solution, and the same treatment was repeated as before. The tissue fragments were treated a total of 56 times in the trypsin-DNAse solution, and the supernatant was removed each time and added to the trypsin inhibitor solution. After the final treatment, the tissue fragments were also added to the trypsin inhibitor solution and centrifuged at $1000 \mathrm{rpm}$ for $10 \mathrm{~min}$. The supernatant, which contained the enzymes, inhibitor, and broken cell fragments, was discarded. The pellet of tissue fragments and cells was resuspended in growth media (without serum) using trituration, and then filtered through several layers of cheesecloth. The density and viability of filtered cells were assessed using a hemacytometer and trypan blue staining, respectively. Cells were diluted to approximately $10^{6}$ cells/cc and plated in growth media (with serum) on poly-D-lysine-coated glass coverslips (no. $1,18 \mathrm{~mm}$; Bellco, Vineland, NJ).

Dissociated cells were either analyzed immediately (i.e., $1-3 \mathrm{hr}$ after dissociation) or placed into 12-well culture dishes (Costar, Cambridge, MA). All cultures were maintained in a growth medium containing Minimal Essential Medium with Earle's salts but without glutamine (MEM; Gibco, Grand Island, NY). The standard growth medium was supplemented with additional potassium chloride (total, $25 \mathrm{~mm}$ ), glu- cose (total, $6 \mathrm{gm} /$ liter), $\mathrm{NaHCO}_{3}$ (total, $3.7 \mathrm{gm} /$ liter), $2 \mathrm{~mm}$ glutamine, heat-inactivated horse serum ( $10 \%, \mathrm{vol} / \mathrm{vol}, \mathrm{Gibco})$, and $\mathrm{N}_{3}$ supplement (Romijn et al., 1982). For some experiments, the additional potassium chloride was omitted. All cultures were maintained at $37^{\circ} \mathrm{C}$ in a humidified environment of $90 \%$ air $/ 10 \% \mathrm{CO}_{2}$ (NAPCO, model 4600 , Portland, OR), and culture medium was replaced 3 times per week.

Immunocytochemistry. Cells were rinsed in Krebs saline and fixed for $30 \mathrm{~min}$ with $4 \%$ paraformaldehyde in $0.1 \mathrm{M}$ phosphate buffer solution. The immunostaining methods we used involved either peroxidase-antiperoxidase (PAP) or avidin-biotin complex (ABC) techniques. The PAP procedures were identical to those we have described previously (Hockberger et al., 1987a). For the ABC method we used the Vectastain ABC kit from Vector Labs (Burlingame, CA). With both $\mathrm{PAP}$ and $\mathrm{ABC}$ methods, positive staining was detected using 3-amino9-ethylcarbazole (AEC) as the substrate for antibody-bound HRP. All preparations were counterstained with hematoxylin. Polyclonal antibodies against neuron-specific enolase (NSE) and S-100 protein were purchased from DAKO Corp. (Santa Barbara, CA). Monoclonal antibodies for THY-1 receptor and LEU-4 antigen were purchased from Miles Scientific (Naperville, IL) and Beckton Dickinson (Towsen, MD), respectively. Polyclonal antibodies for cyclic GMP-dependent protein kinase (GK) and peptide-19 (PEP) were gifts from Drs. Angus Nairn and Paul Greengard (Rockefeller University, New York, NY) and Dr. James Morgan (Roche Institute of Molecular Biology, Nutley, NJ), respectively. The primary antibodies were tested initially at various dilutions, and the following dilutions gave the best results (i.e., best selectivity under our conditions): GK, 1:2000; LEU-4, 1:20; PEP, 1:1000; NSE, 1:1000; S-100, 1:1000; THY-1, 1:75.

Electrophysiology. We used whole-cell patch-recording techniques as described by Hamill et al. (1981). The equipment and procedures we used for recording from cultured cells have been described previously (Hockberger et al., 1987a). Briefly, we used a List EPC-7 patch-clamp amplifier (Medical Systems, Great Neck, NY) and an inverted Nikon microscope (Diaphot). The recording electrodes were pulled and polished using Narishige puller and microforge. The electrodes were filled with the following internal saline solution (in mM): $140 \mathrm{KAc}, 2 \mathrm{MgCl}_{2}$, $1 \mathrm{CaCl}_{2}, 10$ EGTA, 10 HEPES buffer adjusted to pH 7.2. Cells were bathed in the following modified Krebs saline $(\mathrm{mM}): 120 \mathrm{NaCl}, 5.4 \mathrm{KCl}$, $1.8 \mathrm{CaCl}_{2}, 1 \mathrm{MgCl}_{2}, 25$ glucose, $10 \mathrm{HEPES}$ buffer adjusted to $\mathrm{pH} 7.6$. All recordings were made at room temperatures $\left(19-22^{\circ} \mathrm{C}\right)$.

Calcium imaging. Cells were loaded with the calcium indicator fura2/AM and monitored using a CCD-based imaging system as described elsewhere (Connor, 1986; Connor et al, 1987).

\section{Results}

Our strategy for studying the electrophysiological development of rat PCs was to divide the process into 4 stages based in part upon anatomical criteria (Addison, 1911; Altman, 1972, 1982; Altman and Bayer, 1985) and partly upon physiological evidence regarding the timing of synaptogenesis in the cerebellar cortex (Woodward et al., 1969, 1971; Crepel, 1972; Crepel et al., 1976; Shimono et al., 1976). Stage 1 was defined as the period between the birthdate of PCs on embryonic day 15 (E15) and the completion of $\mathrm{PC}$ migration into the primordial cerebellum on embryonic day 22 (E22). PCs at the end of this stage have small round somata $(8-10 \mu \mathrm{m})$ with $3-5$ dendrites and a distinct axon. These cells do not stain with Golgi methods (Hendelman and Aggerwal, 1980) and are thought to be electrically silent (Woodward et al., 1969, 1971). Stage 2 spanned postnatal days 1-4 (P1-P4), and during this period PCs display numerous perisomatic processes upon which climbing fibers form functional synapses (Crepel et al., 1976; Shimono et al., 1976). By stage 3, postnatal days 5-9 (P5-P9), PC somata are larger (12$15 \mu \mathrm{m})$ and synaptic spines pepper the perisomatic processes (presumably marking the location of climbing fiber synapses). During this stage, the somata have become aligned in a single row, and each has produced a thick apical dendrite oriented perpendicular to the cortical surface. During stage 4, P10-P14, further development is denoted by the appearance of extensive 
lateral branching of the apical dendrite in a relatively planar geometry parallel to adjacent PCs. The disappearance of the perisomatic processes leaves a smooth flask-shaped appearance to the somata. Spines on the somata are replaced by spines on the main dendrites and branches. Synaptic contact between PCs and other cells within the cerebellar cortex (granule, basket, stellate, and other PCs), as well as contact with processes from outside the cerebellum (e.g., locus coeruleus and raphe fibers), occurs during this period (Shimono et al., 1976; Waddington and Banks, 1981). Beyond P14, PCs take on the appearance of the adult cell type displaying extensive dendritic arborizations and random hexagonal patterns (Altman and Winfree, 1977).

\section{Immunocytochemical identification of acutely isolated Purkinje cells}

We distinguished acutely isolated PCs from other cerebellar cell types using cell-specific immunocytochemical staining. Antibodies against GK, LEU-4 antigen, and PEP were used because they have been shown to stain PCs selectively in tissue sections from adult rat ccrcbcllum (Lohmann ct al., 1981; Garson et al., 1982; Mugnaini et al., 1988). We found that these markers were also expressed in developing PCs. Figure 1 shows examples of PCs isolated at each stage, fixed and stained for these antigens $1 \mathrm{hr}$ after plating. At stage 1 (E20-E22) immunopositive PCs were similar in size to unstained cells $(8-10 \mu \mathrm{m}$ in diameter) but could be distinguished by the presence of several immunonegative processes $20-30 \mu \mathrm{m}$ long. By stage 2 (P1-P4) PC somata were slightly larger than unstained cells and displayed numerous short perisomatic processes that were immunonegative. By stage 3 PCs were uniformly larger (12-15 $\mu \mathrm{m})$, and the perisomatic processes were now immunopositive. The distinctive apical dendrites seen in vivo at stage 3 were usually absent, presumably due to resorption during the dissociation procedure, although occasionally cells with apical dendrites were isolated at earlier stages (e.g., LEU-4 stain at stage 1, and NSE stain at stage 2). By stage 4 (P10-P14) PCs were uniformly 15 $\mu \mathrm{m}$ in diameter and no longer displayed perisomatic processes. Instead the cell bodies had a smooth, round shape similar to what is expected for PC somata at this stage in vivo. Staining for PEP was especially intense at stage 4 resulting in an overstained, blackened appearance of the cells.

In addition to these PC-specific stains, we also tested cells for several less specific markers including neuron-specific enolase (NSE), THY-1 receptor, and S-100 protein. When we stained the isolated cells for NSE and THY - 1, we found that each stained PCs selectively during stages $1-2$, but thereafter stained other cells as well (Fig. 1, NSE arrows). This is consistent with what is known about these antigens in vivo; that is, NSE and THY-1 are found selectively in PCs around birth, but during the second postnatal week each is expressed in other cerebellar neurons (Barclay, 1979; Schmechel et al., 1980; Morris et al., 1985). S-100 protein is found in adult PCs and in glial cells (Tabuchi et al., 1976), and we found that S-100 was present in isolated PCs and small round cells (presumably glial cells) during all 4 stages of development. As with PEP, the staining intensity for NSE, THY-1, and S-100 increased in PCs with development.

\section{Electrophysiological properties of acutely isolated Purkinje cells}

Having established some characteristic features of PCs at each stage of development, we then used these features to select unstained PCs for electrophysiological measurements. Intracellu- lar recordings from isolated PCs were performed at each stage of development, and resting potentials ranged from -41 to -58 $\mathrm{mV}$, with a mean of $-49.5 \mathrm{mV}(\mathrm{SD}=5.5 \mathrm{mV}, n=37)$. No significant difference in the average resting potential was found between stages. Cell input resistance, on the other hand, decreased from a mean of $0.8 \mathrm{G} \Omega$ in stage 1 ( $\mathrm{SD}=0.2 \mathrm{G} \Omega, n=$ 9) to $0.3 \mathrm{G} \Omega$ by stage $4(\mathrm{SD}=0.2 \mathrm{G} \Omega, n=5)$. Spontaneous electrical activity was absent at all stages, although at stages 24 action potentials could be evoked with current stimulation. Figure 2 shows recordings from PCs taken at stages $2-4$ showing the progressive change in the shape of the spike with development. At P3 the action potential was broad and did not overshoot $0 \mathrm{mV}$. By P12 the spike amplitude had a $10-20 \mathrm{mV}$ overshoot, and the duration was approximately one-half of spikes at earlier stages. With stimulation of longer duration, cells at stage 4 occasionally generated 2-3 spikes before adapting.

Voltage-dependent membrane conductances also displayed changes in amplitude and shape during development. Representative examples are shown in Figure 3 where the membrane currents at each stage were measured under voltage clamp. Currents were evoked using positive voltage steps (in $20 \mathrm{mV}$ increments) from a holding potential of $-60 \mathrm{mV}$. At E20 only the hint of a voltage-dependent outward current was apparent. This was the case for 8 of the 9 cells tested between E20 and E21. During stage 2 small inward and outward currents were recorded from all cells examined $(n=17)$. The currents evoked from PCs at stage $3(n=4)$ and stage $4(n=5)$ were larger and more complex in shape. A transient outward current (arrows in $\mathrm{P} 9$ and $\mathrm{P} 12$ ) was activated in the older cells with positive steps above $-20 \mathrm{mV}$. This outward current was also activated from holding potentials of $-40 \mathrm{mV}$, and therefore it was unlikely to be due to an A-current (see Rogawski, 1985). It may have been a calcium-activated potassium current (see following section), although we have not yet analyzed the conductances in detail.

Membrane responses to iontophoretically-applied glutamate wcre also compared during development. Between E20 and E21 only 1 out of 9 PCs was depolarized by glutamate. Even at P1, when action potentials were already apparent, only 1 out of 8 cells responded to glutamate. However, between $\mathrm{P} 2$ and $\mathrm{P} 3$, all PCs examined $(n=9)$ were depolarized by glutamate. The amplitude of the maximum depolarization increased during stage 3 (see insert in Fig. 4) even though the membrane resistance decreased. Further evidence for increased glutamate sensitivity was obtained during measurements of intracellular $\mathrm{Ca}^{2+}$.

\section{Intracellular $\mathrm{Ca}^{2+}$ measurements in acutely isolated Purkinje cells}

Isolated cells were loaded with the membrane-permanent calcium indicator fura $-2 / \mathrm{AM}$, and the response to iontophoretically-applied glutamate was examined at different stages of development. Figure 4 shows the intracellular free $\mathrm{Ca}^{2+}$ concentration of PCs before, during, and after a 1 sec application of glutamate. Although the data are for individual cells, the group results were similar. There was virtually no response at E21 $(n=4)$, but by P4, 3 out of 4 cells responded to glutamate with small $\mathrm{Ca}^{2+}$ elevations. The mean resting $\mathrm{Ca}^{2+}$ concentration at P4 was estimated to be $80 \mathrm{nM}(\mathrm{SD}=10 \mathrm{nM})$ compared with $25 \mathrm{nM}(\mathrm{SD}=5 \mathrm{nM})$ for $\mathrm{E} 21$ cells. By P7, the average resting $\mathrm{Ca}^{2+}$ level was $120 \mathrm{nM}(\mathrm{SD}=20 \mathrm{nM}, n=9)$, and the average peak response to glutamate was $730 \mathrm{nM}(\mathrm{SD}=140 \mathrm{nM})$. As with the smaller $\mathrm{Ca}$ responses of earlier stages, recovery in the older 
NSE
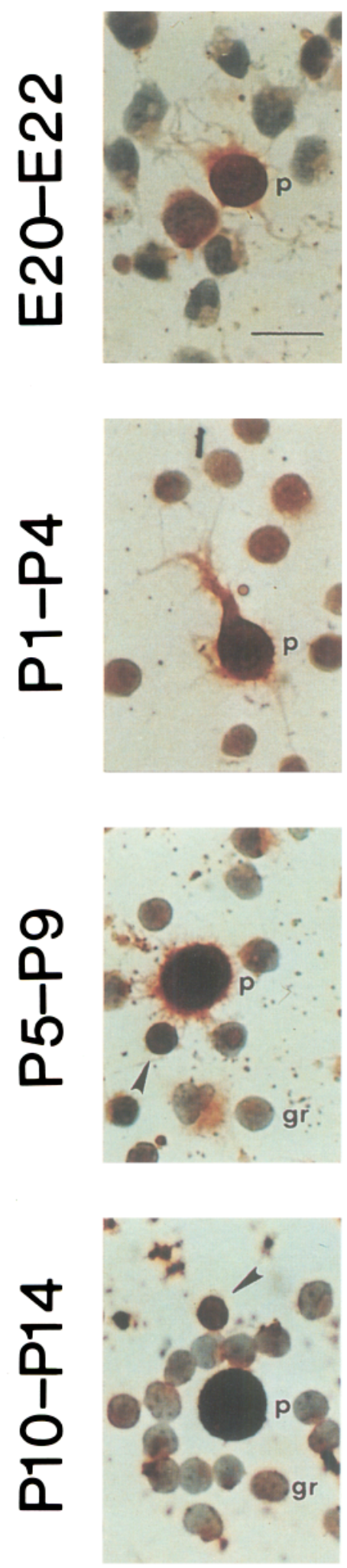

PEP
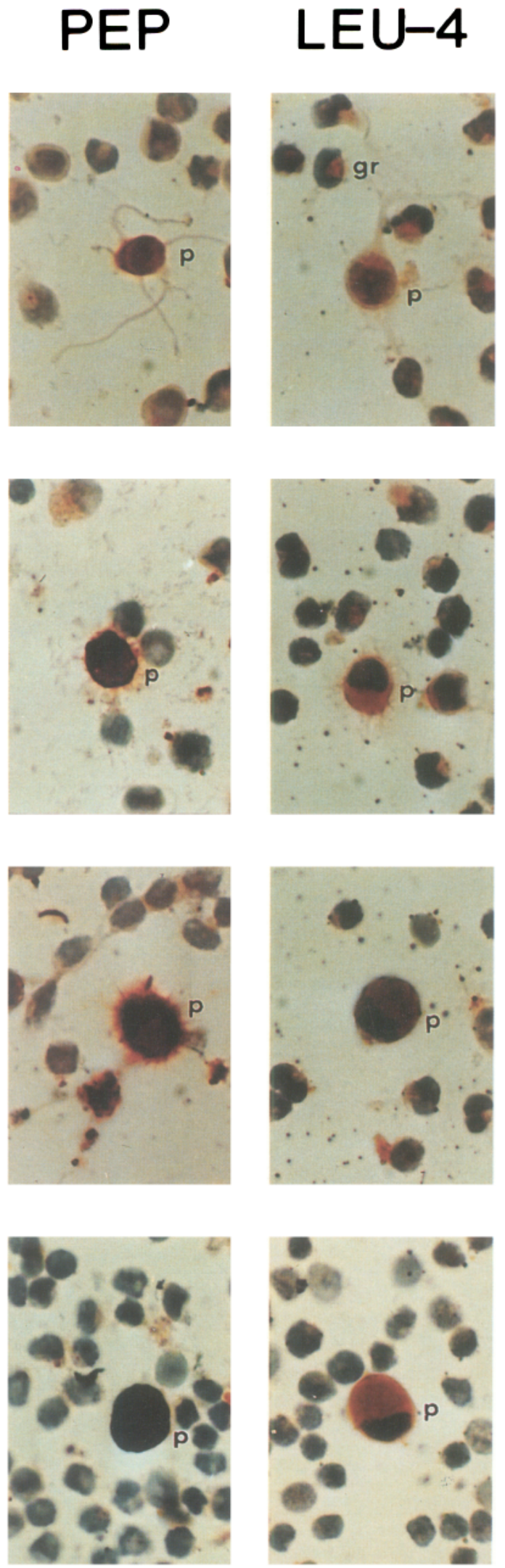
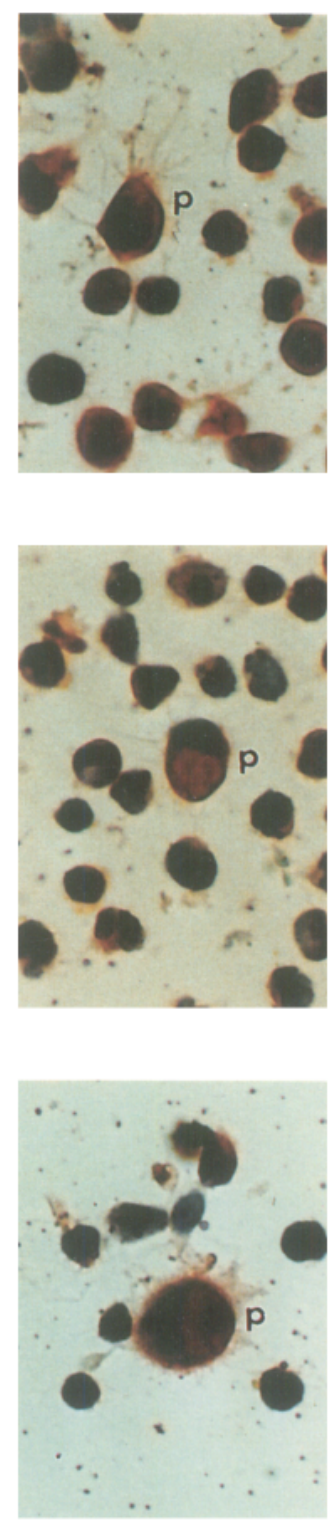

GK

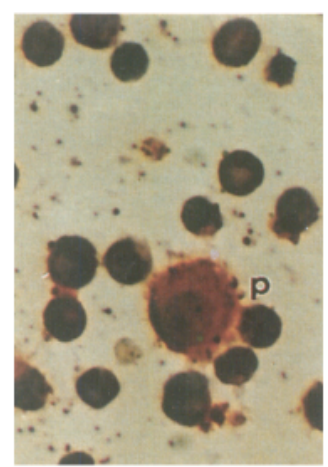

Figure 1. Acutely isolated Purkinje cells ( $p$ ) were identified using imunocytochemical staining for NSE, PEP, LEU-4, and GK at 4 stages of development: embryonic days 20-22 (E20-E22), postnatal days 1-4 (P1-P4), 5-9 (P5-P9), and 10-14 (P10-P14). Positive staining is indicated by red-black, and the nuclei of all cells were counterstained with hematoxylin (blue). Granule cells ( $g r$ ) developed staining for NSE in the later stages (arrows). Scale bar, $15 \mu \mathrm{m}$. 


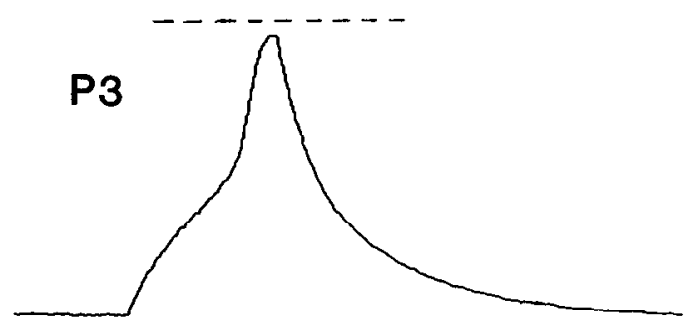

$\underline{I}$

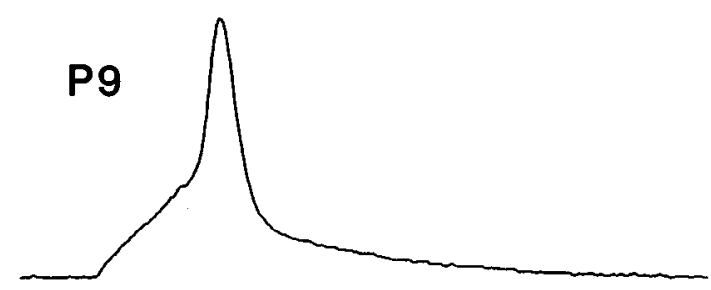

I

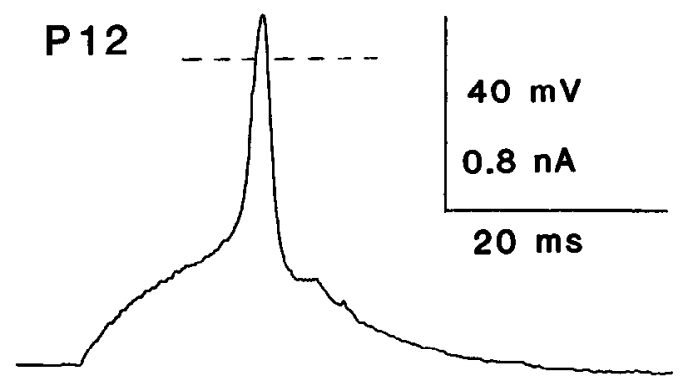

I

Figure 2. Comparison of action potentials of isolated Purkinje cells at 3 stages of development (P3, P9, P12). The spike, elicited with current stimulation $(I)$, was approximately double in height and one-half in duration at $\mathrm{P} 12$ compared with $\mathrm{P} 3$. Dotted lines denote $0 \mathrm{mV}$. Calibrations are the same for all records. Resting potentials were $-55(\mathrm{P} 3)$, -61 (P9), and $-63 \mathrm{mV}$ (P12).

sells was complete within $30 \mathrm{sec}$ after glutamate application. These results are consistent with recent electrophysiological evidence indicating that voltage-dependent Ca currents are present in the cell bodies of developing PCs (Regan, 1987).

\section{Conditions for Purkinje cell differentiation in long-term culture}

We have previously shown that cerebellar granule cells differentiate electrophysiologically and immunocytochemically when grown in explant cultures. Our attempts to study explanted PCs was hindered because these cells, unlike granule cells, remained inside the explant. We found this to be the case whether we cultured early postnatal or late embryonic tissue. Figure 5 shows an example of an E21 cerebellar explant fixed and stained for PEP after $10 \mathrm{~d}$ in culture. The results show that most of the PCs
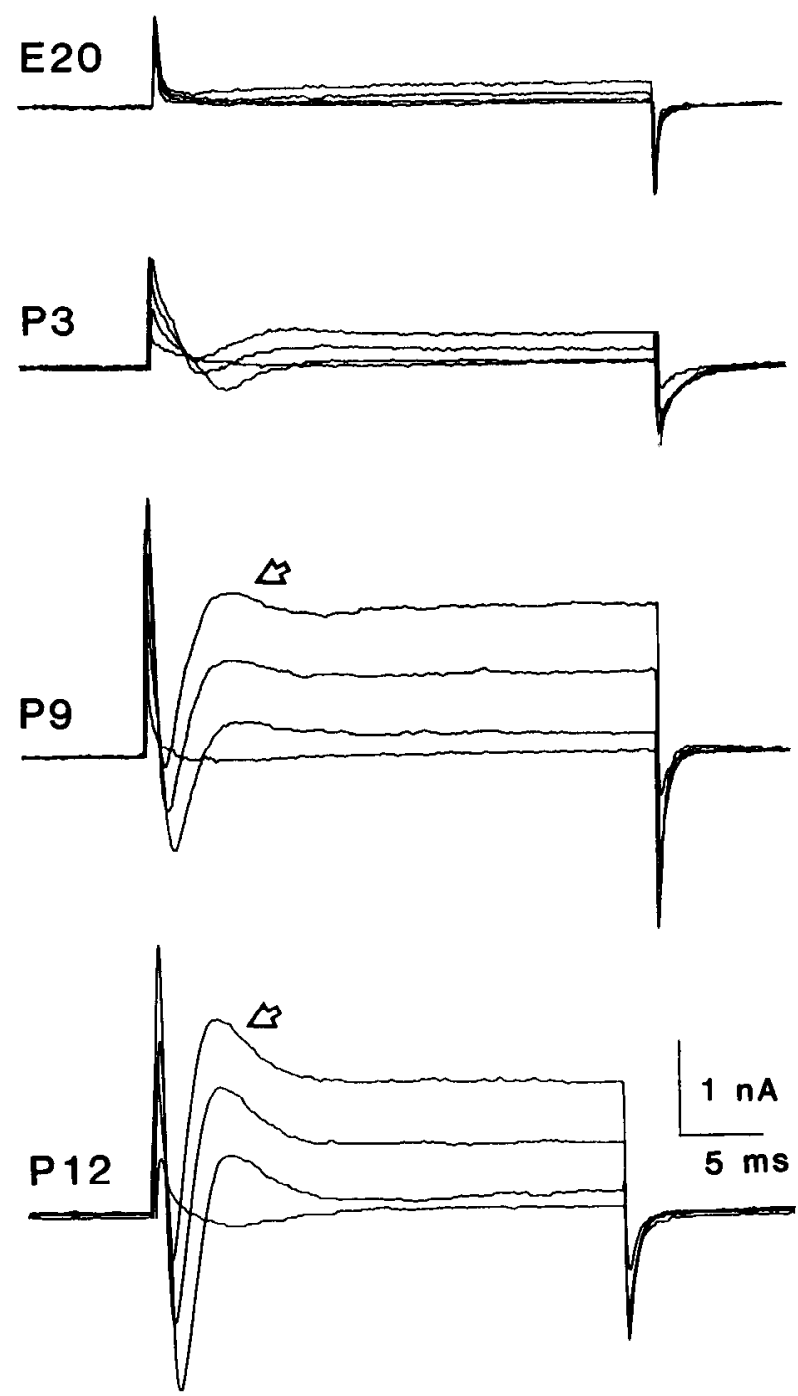

Figure 3. Comparison of voltage-dependent conductances from isolated Purkinje cells representing each stage of development (E20, P3, P9, P12). Membrane currents for each cell were generated using positive voltage steps in $20 \mathrm{mV}$ increments from a holding potential of -60 $\mathrm{mV}$. The records from $\mathrm{P} 3, \mathrm{P} 9$, and $\mathrm{P} 12$ were from the same cells used for Figure 2.

were gathered into groups either at the edge of or buried within the explant. Without staining, the cells were hidden from view, and thus we were unable to perform patch-clamp measurements under these conditions. Similar results were also found after several weeks in vitro.

We next attempted culturing PCs following tissue dissociation using the same culture conditions we used for the explant experiments. As in earlier studies (Fields et al., 1982; Messer et al., 1984; Weber and Schachner 1984), we too found that PCs dissociated from embryonic tissue survived and differentiated better in culture than PCs from postnatal tissue. Specifically, rat $\mathrm{PCs}$ dissociated between E20 and $\mathrm{P} 2$ developed extensive dendritic branching after several weeks in culture, while PCs from older animals (P3-P14) did not. Figure 6 shows examples of cells dissociated at 3 different stages of development (P2, P7, $P 14)$, then fixed and stained for PEP after approximately 1 month in culture. We found that PCs in the P7 $(B)$ and P14 (C) cultures sometimes survived but displayed poor morphological differ- 


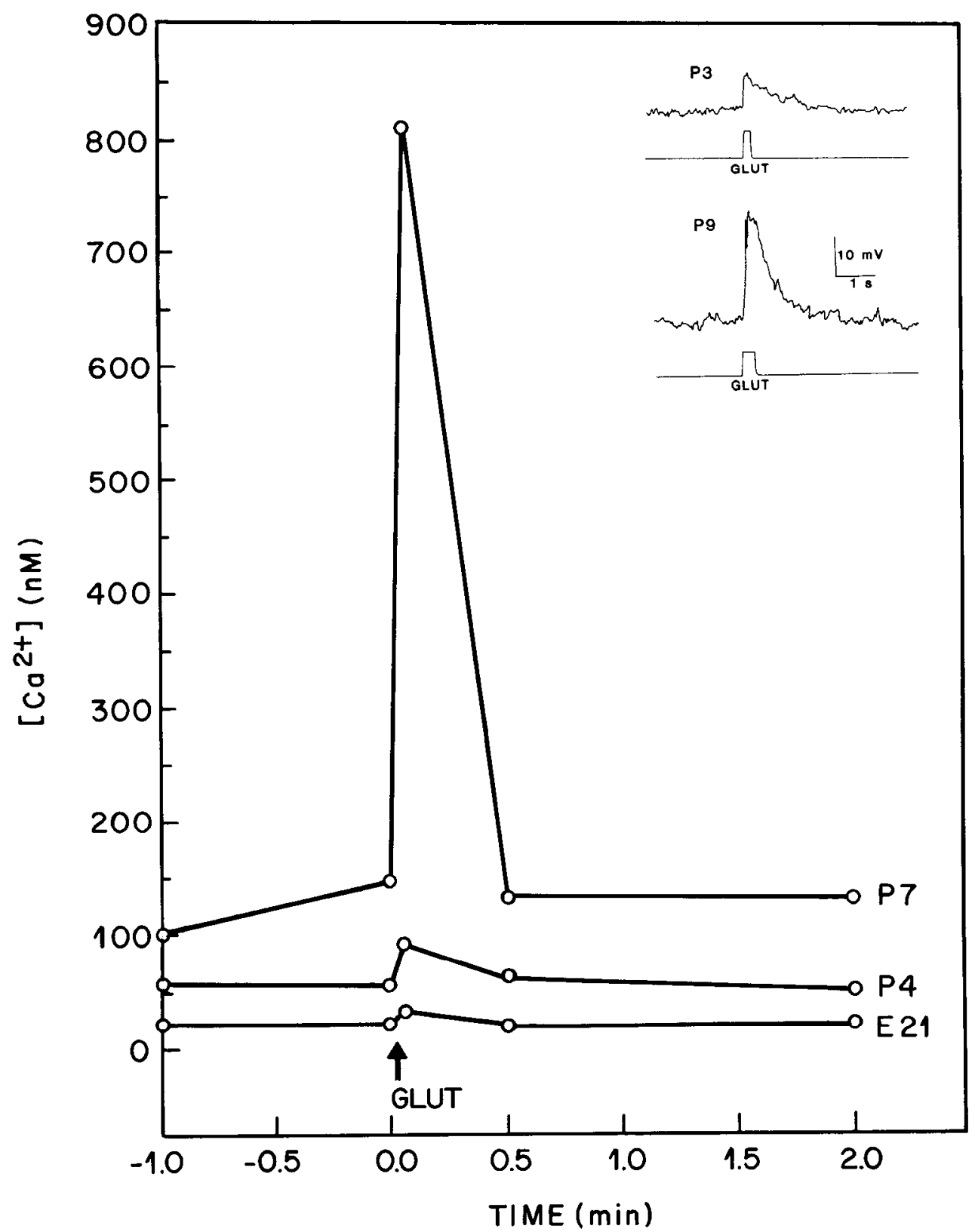

Figure 4. Ca responses measured with fura-2 of Purkinje cells isolated at different stages of development (E21, P4, P7). Both the resting concentration of intracellular free $\mathrm{Ca}^{2+}$ and the amplitude of the transient Ca-response to iontophoretically applied glutamate gradually increased with development. Inset, Examples of membrane potential responses to glutamate at similar stages (resting potentials were comparable). entiation compared with the cells in the $\mathrm{P} 2(A)$ culture. The number of PCs displaying a differentiated morphology was even greater in cultures of embryonic tissue (see below).

Weber and Schachner (1984) reported that PC survival and differentiation was enhanced in serum-free medium, while cells growing in serum-containing medium lacked morphological differentiation. We too observed that PCs grown in serum-containing medium did not differentiate. However, we found that if the medium was supplemented with high potassium $(25 \mathrm{~mm})$, then differentiation was enhanced even though serum was present (also see Lasher and Zagon, 1972; Fields et al., 1982). This was evident not only in the degree of morphological differentiation of cultured PCs, but also in their electrophysiological differentiation (see following section). Attempts to mimic the positive effects of high potassium by substituting either glutamate $(0.5$ or $5 \mu \mathrm{M})$ or aspartate $(0.5$ or $5 \mu \mathrm{M})$ in the medium were unsuccessful. In fact, these treatments were toxic to all cells, which rarely survived under these conditions for more than 1-2 weeks. On the other hand, PCs from embryonic tissue grown in high-potassium, serum-supplemented medium survived as long as the cultures were maintained (up to $80 \mathrm{~d}$ ).

Having established a set of conditions that facilitated the longterm survival and differentiation of dissociated PCs in culture, we next focused on their morphological development over time. Figure 7 shows the shape of E20 PCs fixed and stained for PEP after different periods in culture. [We did not use tissue earlier than E20 due to difficulty in defining the boundary of the cerebellum at earlier times, and because Altman and Bayer (1985) have shown that $\mathrm{PC}$ migration into the primordial cerebellum is not complete until late embryonic periods.] After 2 weeks in vitro, PCs had a stellate appearance with many short perisomatic processes and one long extension, most likely the axon (arrow in Fig. 7A). By 2-3 weeks, the perisomatic processes were replaced by several thicker outgrowths giving the cell body a crab- 

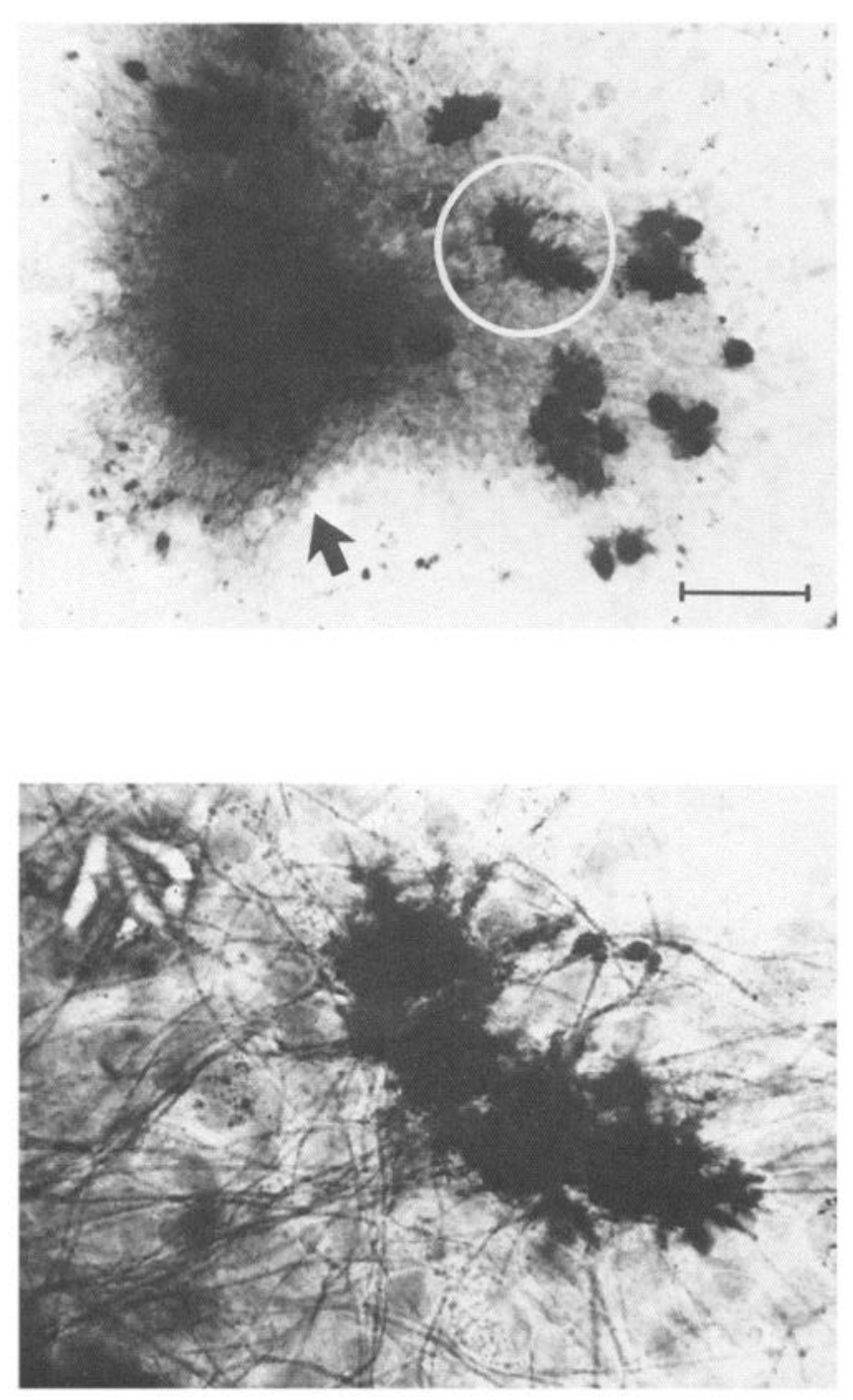

Figure 5. PEP immunostaining of explanted E21 cerebellum demonstrated that the Purkinje cells remained primarily inside the host tissue. Top, Low magnification showing groups of immunoreactive Purkinje cells located at the edge of the explant (circle) and buried inside the explant (arrow) after $10 \mathrm{~d}$ in culture. Bottom, Higher magnification of circled area showing 4 Purkinje cells in the early stages of differentiation. Scale bar, $50 \mu \mathrm{m}$ (top) and $12.5 \mu \mathrm{m}$ (bottom).

like appearance (Fig. $7 B$ ). This shape is similar to what was seen in explants after 1-2 weeks (cf. Fig. 5). After 3-4 weeks, the PC somata appeared smooth and displayed a thick primary dendrite with secondary branching (Fig. $7 C$ ). Figure $7 D$ shows a PC after 5 weeks in culture that had developed 2 primary dendrites with extensive dendritic branching and bulbous swellings reminiscent of "giant" spines that develop in vivo in the absence of granule cells (Berry and Bradley, 1976; Hillman and Chen, 1981). However, granule cells were present in our cultures.

There was substantial variability in the morphology of PCs after a month in culture, and some examples are shown in Figure 8. The variability was manifested in 3 ways: the number of primary dendrites, the orientation of the dendritic tree, and the size of the cell body. The number of primary dendrites was variable including one (Fig. $8 A$ ), two (Fig. $8, B, E$ ), three (Fig. $8 C$ ), or more, giving some cells a stellate appearance (Fig. $8 D$ ).
When 2 primary dendrites were present, they sometimes emerged from the same side of the cell body (Fig. $8 E$ ) and sometimes from opposite sides (Figs. $7 D, 8 B$ ). The soma diameter of the majority of PEP-positive cells ranged from 15 to $20 \mu \mathrm{m}$. However, smaller $(8-10 \mu \mathrm{m})$ and larger cell bodies $(25-30 \mu \mathrm{m})$ were also found, as shown in Figure $8 F$.

We also examined the staining profile of cultured cells with other PC-related antigens: GK, LEU-4, NSE, THY-1, and S-100. Although we could identify cells that stained positive for each of these markers after 2-4 weeks in culture, there were several drawbacks to using them for identifying PCs. NSE stained all neurons after 1 month in culture and was therefore nonspecific. GK, LEU-4, and S-100 only stained cell bodies even after 2 months in vitro, giving no indication of the extent of dendritic outgrowth in the cells. Also the intensity of staining in the cultured PCs, unlike the acutely isolated cells, did not coincide with the electrophysiological maturation of the cells. That is, the intensity of staining remained constant for GK, S-100, and THY-1 up to 1 month in culture, even though PCs were developing excitability (see below). Staining for LEU-4 decreased beyond 2 weeks in culture. Finally, granule cells developed positive immunoreactivity to GK after several weeks in culture. Granule cells do not stain for GK in tissue sections (Lohmann et al., 1981), although granule cells do synthesize cGMP in culture (Novelli and Henneberry, 1987). Thus, the GK staining of cultured granule cells may reflect either a level of GK production in culture that is not detectable in tissue sections or an abnormal production of GK in culture.

\section{Electrophysiological properties of Purkinje cells in long-term culture}

As mentioned above, morphological differentiation occurred only if cells were dissociated prior to P2 and then grown in medium containing high potassium. This was also the case for electrophysiological differentiation. Table 1 summarizes our electrophysiological results for cells isolated at stages $1-4$ and grown in either normal ( $5 \mathrm{~mm})$ or high-potassium medium $(25$ mм). Stage 1 cells developed action potentials (and glutamate responses) during the first 2 weeks in culture only when grown in high-potassium medium. This excitability persisted for up to $80 \mathrm{~d}$ (at which time the cultures were terminated). Stage 2 cells, which were weakly excitable at the time of dissociation (cf. Fig. 2), gave mixed results during the first 2 weeks in high potassium: 9 out of 22 cells displayed excitability. Beyond 2 weeks, the percentage of excitable cells increased in high-potassium saline, while cells in normal potassium were inexcitable throughout. Stage 3 and 4 cells rarely survived even in high-potassium saline. Those that did survive lost their excitability regardless of whether high potassium was present or not. The smaller sampling of cells for stages 3 and 4 reflects the decreased number of PCs that survived under these conditions.

The following results were obtained for embryonic PCs cultured in high-potassium medium for at least $30 \mathrm{~d}$. Some cells displayed spontaneous electrical activity, and an example is shown in Figure $9 \mathrm{~A}$. In this example, the waveform was composed of recurring doublets separated by short hyperpolarizations. When the cell was hyperpolarized with current stimulation, discrete bursts of activity with large interburst hyperpolarizations were induced (Fig. 9B). Each burst was a complex waveform involving a fast depolarization followed by a plateau phase during which individual spikes occurred. Single bursts with similar waveforms were also elicited from quiescent 

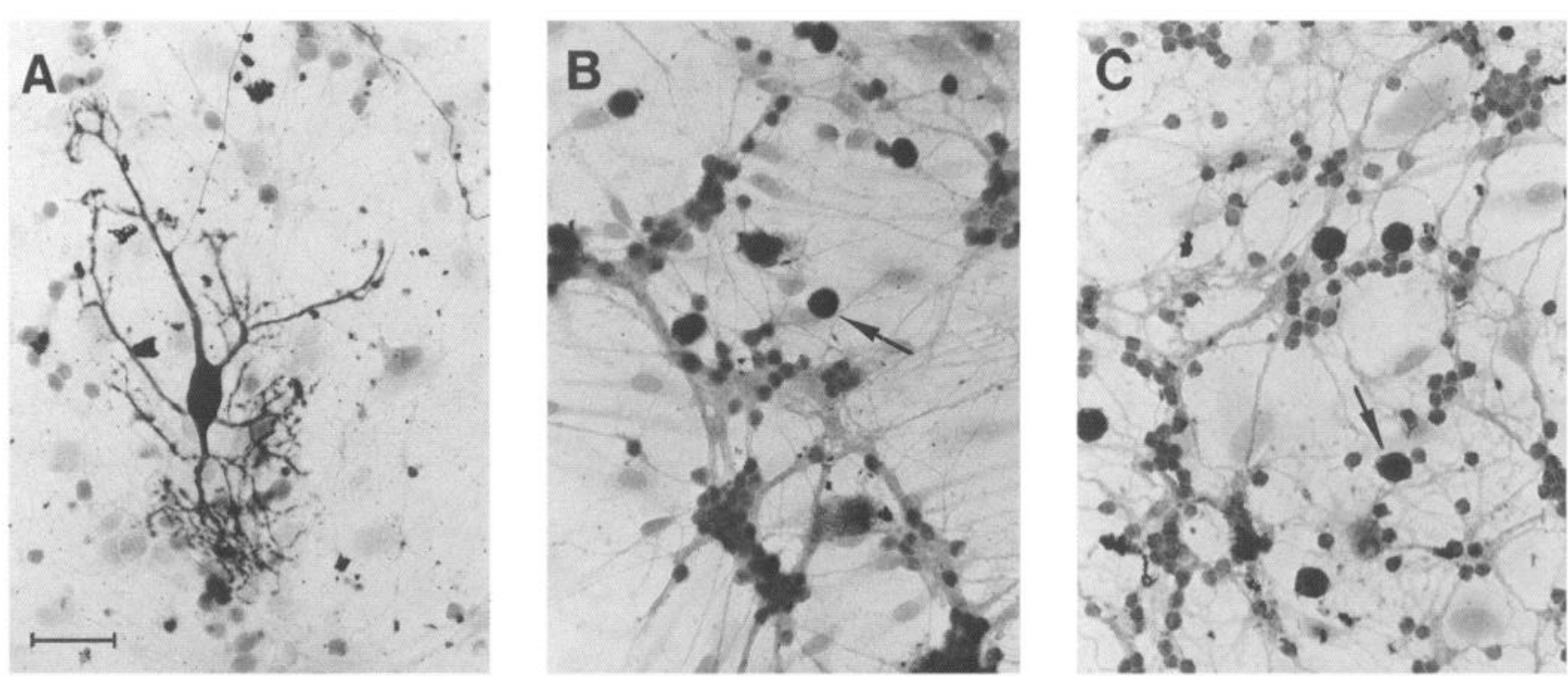

Figure 6. PEP immunostaining of cultured Purkinje cells dissociated from cerebella at stages $2-4$ and cultured in high-potassium media. A, Cell from stage 2 (P2) after $38 \mathrm{~d}$ in culture displayed several thick processes with secondary branching. By comparison, Purkinje cells dissociated at later stages, i.e., P7 $(B)$ or P14 $(C)$, remained round and poorly differentiated even after 35 and 31 d in culture, respectively. The small cells were primarily granule cells which fluorished in all 3 cultures. Scale bar, $25 \mu \mathrm{m}$.

PCs using either current stimulation (Fig. $9 C$ ) or glutamate application (Fig. 9, $D-F$ ). Figures $9 C$ and $9 D$ were evoked from the same cell, demonstrating that the shape of the response was similar regardless of how it was evoked. These complex waveforms are reminiscent of $\mathrm{PC}$ responses induced in vivo by climbing fiber stimulation (see Discussion).

Analysis of membrane currents under voltage clamp was impeded by the extensive dendritic processes present in cultured PCs. An example is given in Figure 10, which shows the cell membrane potential held at $-60 \mathrm{mV}$ and stepped positive in $20 \mathrm{mV}$ increments. An inward current was activated at -20 $\mathrm{mV}$ after a short delay (solid arrow), and it was followed by a transient outward current (open arrow). Although the shape of the inward and outward currents is similar to those of mature PCs in isolation (cf. Fig. 3), the delayed inward current suggests that at least part of the total current may have been generated in the processes. A more detailed analysis in the following paper supports this interpretation.

\section{Discussion}

In this report we have analyzed the electrophysiological properties of PCs acutely isolated at 4 stages of development between embryonic day 20 and postnatal day 14. At stage 1 (E20-E22), PCs were inexcitable and did not respond to glutamate. Excitability developed during the first few days after birth (stage 2) and progressed steadily during the following 2 weeks (stages 3 and 4). During that time, PCs displayed increased sensitivity to glutamate and an increased amplitude for several voltage-dependent membrane conductances. Elevation of intracellular free $\mathrm{Ca}^{2+}$ induced by glutamate application also increased during that period. These results support and extend previous studies using extracellular recordings to describe the electrophysiological properties of PCs developing in vivo (Woodward et al., 1969; Crepel, 1972; Crepel et al., 1976; Shimono et al., 1976).

We did not detect spontaneous electrical activity in the isolated PCs at any of these stages, yet several types of indirect

Table 1. Development of excitability in cultured Purkinje cells required high-potassium growth media

\begin{tabular}{|c|c|c|c|c|c|c|c|c|}
\hline \multirow{2}{*}{$\begin{array}{l}\text { Days } \\
\text { in vitro }\end{array}$} & \multicolumn{2}{|c|}{$\begin{array}{l}\text { Stage 1 } \\
\text { (E20-E22) }\end{array}$} & \multicolumn{2}{|c|}{$\begin{array}{l}\text { Stage } 2 \\
\text { (P1-P4) }\end{array}$} & \multicolumn{2}{|c|}{$\begin{array}{l}\text { Stage 3 } \\
\text { (P5-P9) }\end{array}$} & \multicolumn{2}{|c|}{$\begin{array}{l}\text { Stage } 4 \\
(\mathrm{P} 10-\mathrm{P} 14)\end{array}$} \\
\hline & $5 \mathrm{~K}$ & $25 \mathrm{~K}$ & $5 \mathrm{~K}$ & $25 \mathrm{~K}$ & $5 \mathrm{~K}$ & $25 \mathrm{~K}$ & $5 \mathrm{~K}$ & $25 \mathrm{~K}$ \\
\hline $1-14$ & $0 / 4$ & $7 / 7^{a}$ & $0 / 13$ & $9 / 22$ & $0 / 5$ & $1 / 5$ & $0 / 2$ & $0 / 3$ \\
\hline $15-29$ & $0 / 4$ & $14 / 16$ & $0 / 11$ & $7 / 11$ & NS & $1 / 3$ & NS & $0 / 2$ \\
\hline $30-80$ & $0 / 4$ & $31 / 36$ & $0 / 5$ & $13 / 15$ & NS & $0 / 2$ & NS & $0 / 2$ \\
\hline
\end{tabular}

Cells were cultured from each of 4 developmental stages and grown in medium containing either $5 \mathrm{~mm}(5 \mathrm{~K})$ or $25 \mathrm{~mm}$ $(25 \mathrm{~K})$ potassium chloride. At regular intervals, cells were tested in Kreb's saline for the presence of action potentials using current stimulation. The data are presented as the number of cells displaying action potentials/number of cells examined. The number of cells examined in each group reflects the relative survivability under the specified conditions. NS, no survival of Purkinje cells under these conditions.

"Stage 1 cells required several days in culture before excitability was present. 
Figure 7. PEP immunostaining of Purkinje cells dissociated at E21 demonstrated progressive morphological development in culture. $A$, After $13 \mathrm{~d}$, cells displayed many perisomatic processes of uniform size and shape. $B$, By $20 \mathrm{~d}$, perisomatic processes had given way to several discrete primary branches. $C$, Secondary branching was prevalent by $27 \mathrm{~d} . D$. Tertiary branches and spines were visible after $37 \mathrm{~d}$. Long axonlike processes were distinguishable at each phase (arrows). Scale bar, $25 \mu \mathrm{m}$.
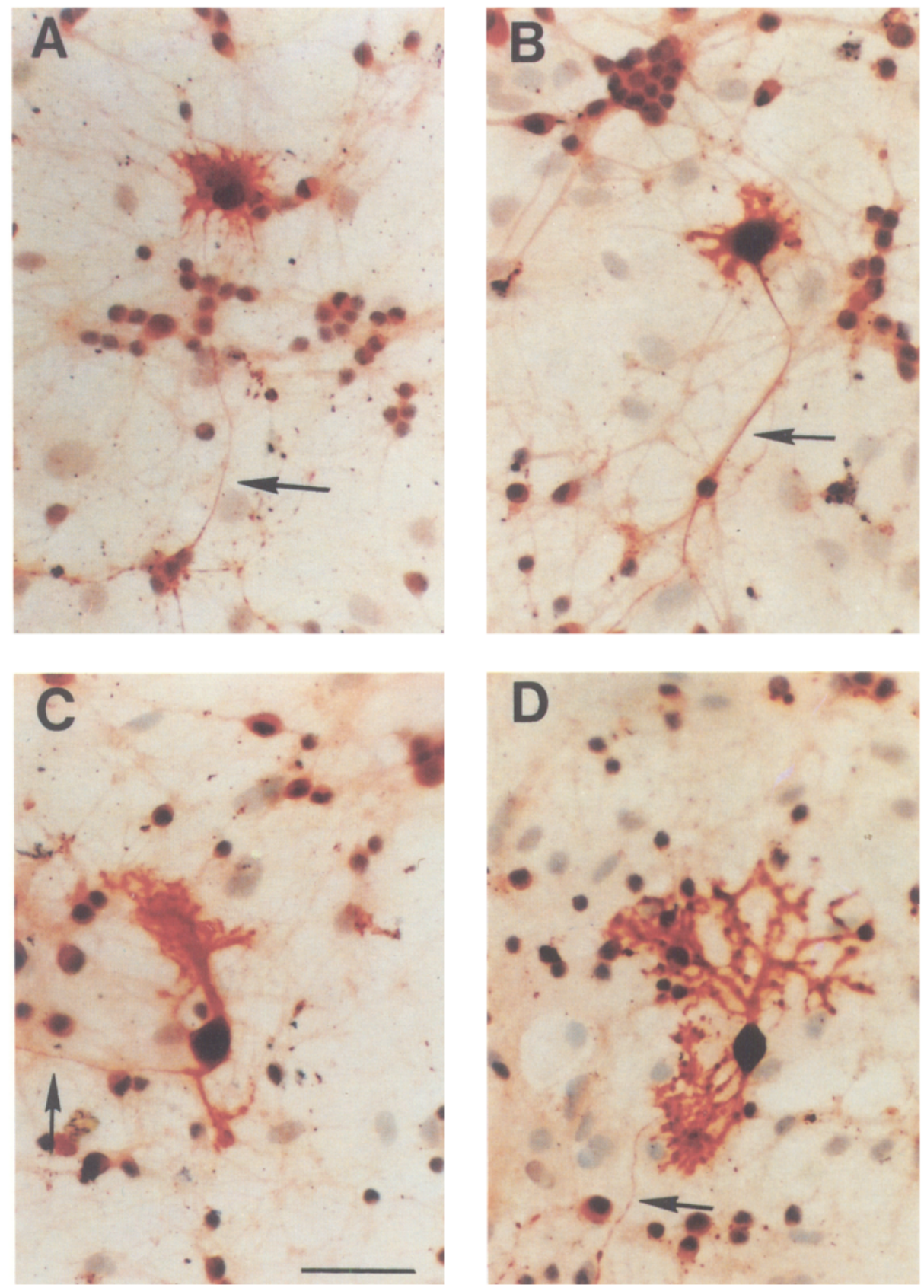

evidence suggest that PCs are capable of endogenous electrical activity. There are basically 4 types of evidence. First, spontaneous activity has been recorded from the $\mathrm{PC}$ layer in vivo as early as $1 \mathrm{~d}$ after birth (Woodward et al., 1969), several days before the first synaptic inputs arrive (Woodward et al., 1971; Crepel, 1971, 1972; Crepel et al., 1976, 1981; Shimono et al., 1976). Second, elimination of the excitatory pathways did not change the frequency of the rhythmic electrical behavior of adult PCs (Snider et al., 1967; Woodward et al., 1974; Siggins et al., 1976; Crepel et al., 1981). Third, half of the cultured PCs examined in high-magnesium saline (used to block synaptic transmission) still generated rhythmic electrical activity (Gahwiler et al., 1973). Fourth, burst activity recorded from adult PCs in cerebellar slices persists in TTX-containing saline (Llinás and

Figure 8. PEP immunostaining of Purkinje cells dissociated at E20 displayed several different shapes after 1 month in culture. The shapes were classified by differences in the number of processes or by the size of the cell body: monopolar cells $(A)$, bipolar cells with processes emanating from opposite sides $(B)$, tripolar cells $(C)$, stellate cells $(D)$, bipolar cells with processes extending from the same side $(E)$, and cells with small and large somata $(F)$. 

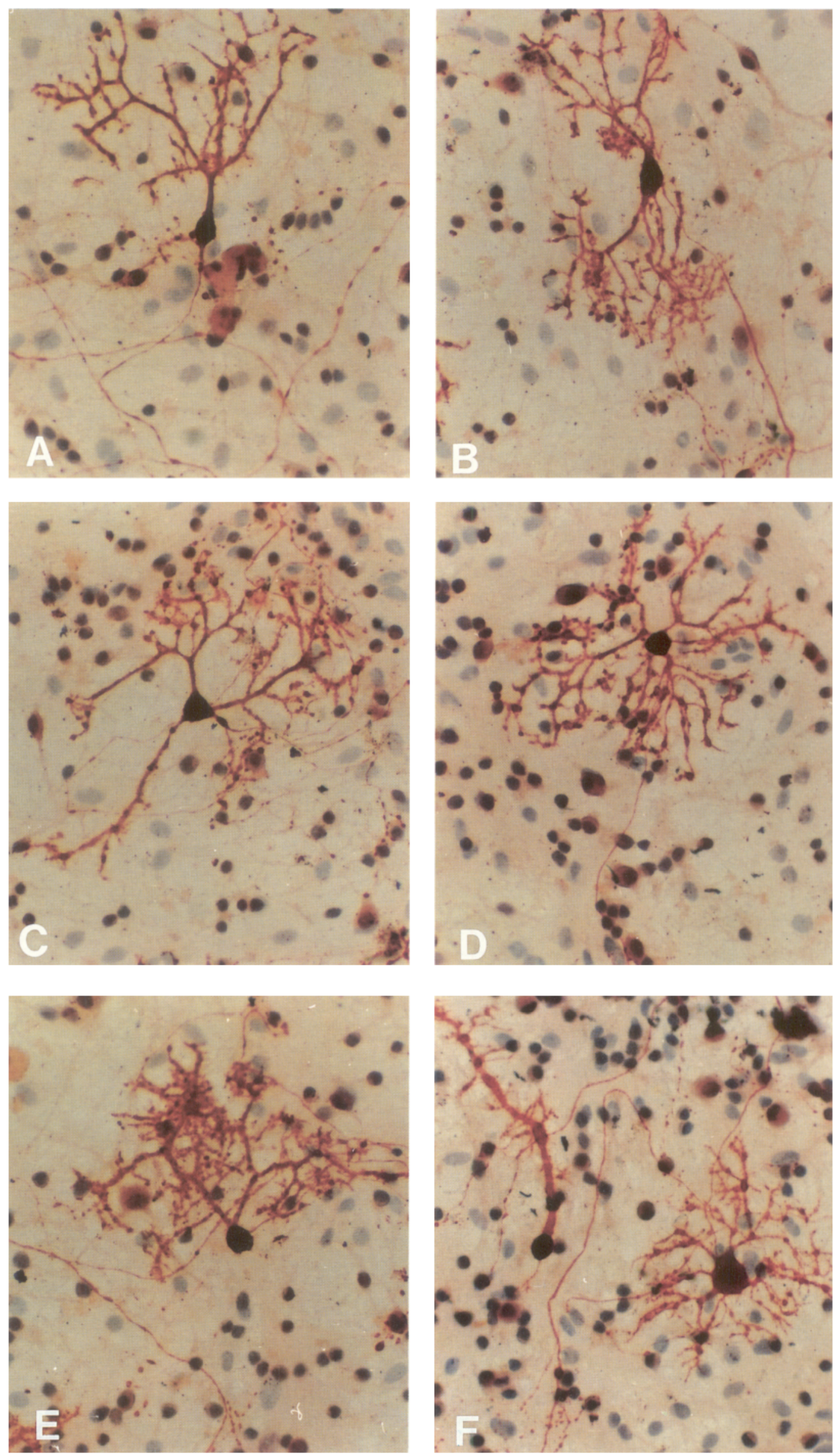

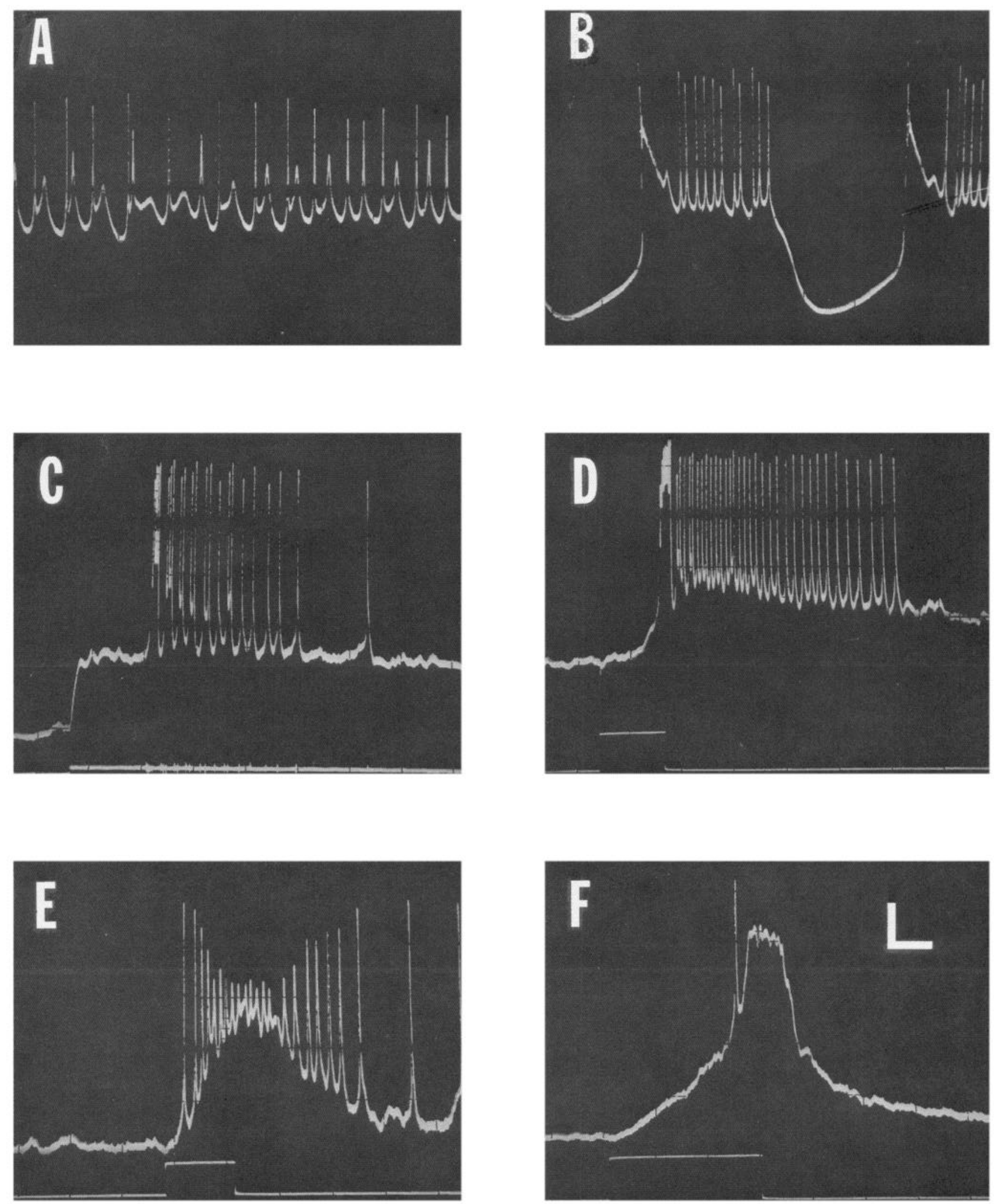

Figure 9. Spontaneous membrane potential oscillations $(A$ and $B)$ and climbing fiber-like responses $(C-F)$ recorded from Purkinje cells after 1 -month in culture. The climbing fiber-like responses were characterized by one or more fast spikes followed by a longer-lasting plateau potential. The records in $A$ and $B$ are from the same cell and show how the waveform of spontaneous oscillations differed when the cell was slightly hyperpolarized $(B)$ using current injection. The records in $C$ and $D$ were obtained from another cell and show that similar responses were elicited with current stimulation in $C$ (bottom trace marks current injection) and iontophoretically applied glutamate in $D$ (bottom trace marks current ejection). The responses in $E$ and $F$ are examples of glutamate-evoked responses obtained from other Purkinje cells. Resting potentials were between -50 and $-65 \mathrm{mV}$ in $C-F$. Scale bar, $10 \mathrm{mV}$ and $200 \mathrm{msec}$ for all traces. 


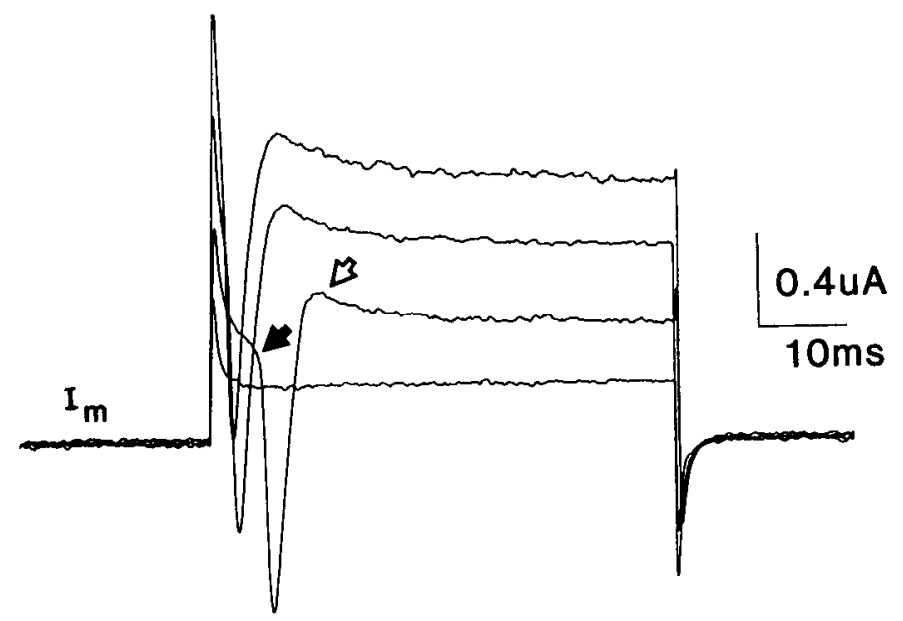

Figure 10. Membrane currents evoked from a cultured Purkinje cell under voltage clamp. Holding potential was $-60 \mathrm{mV}$ and steps were positive in $20 \mathrm{mV}$ increments.

Sugimori, 1980a). Thus, the absence of spontaneous electrical activity in the isolated PCs studied here suggests to us that either these cells develop endogenous activity after P14, or alternatively, the source of pacemaker activity is located in the dendrites (cf. Llinás and Sugimori, 1980b). The possibility of compartmentalization of electrical properties may represent an important limitation of the isolated cell method for studying certain aspects of cell physiology.

In this study we used cell-specific immunocytochemical staining to identify cultured PCs, a strategy also adopted by Fields et al. (1982), Weber and Schachner (1984), Hirano and Ohmori (1986), and Gruol and Franklin (1987). Our most satisfying results were obtained with PEP staining. Unlike the other markers we tried, PEP antigen was expressed in the somatic and dendritic processes of PCs cultured up to $50 \mathrm{~d}$. The absence of dendritic staining for GK, LEU-4, S-100, and THY-1 suggests that our culture conditions were not optimal for the expression of these antigens since they are present in PC dendrites in tissue sections (Lohmann et al., 1981; Garson et al., 1982; Tabuchi et al., 1976; Barclay, 1979). Similar problems with THY-1, LEU4 , and GK can be seen in previous reports of cultured PCs (Fields et al., 1982; Hirano and Ohmori, 1986; Gruol and Franklin, 1987).

Our results with PEP are comparable to those of Weber and Schachner (1984), who used PC-specific monoclonal antibodies generated in their laboratory. Both groups found that the dendritic shapes of cultured PCs were reminiscent of cells found in agranular cerebella where dendritic trees are extensive but disoriented (Altman and Anderson, 1972; Hirano and Dembitzer, 1973; Rakic and Sidman, 1973; Sotelo, 1975; Berry and Bradley, 1976; Mariani et al., 1977). Weber and Schachner reported that PC differentiation was enhanced with higher cell plating densities and by the presence of serum-free media. Although we did not address the question of seeding density, we found that morphological and electrophysiological differentiation was possible in serum-containing medium if $25 \mathrm{~mm}$ potassium chloride was included. Therefore it does not appear that serum contains some factor preventing PC differentiation.

The beneficial effects of high-potassium on the survival and differentiation of cultured neurons has been well-documented (Scott and Fisher, 1970; Scott, 1971, 1977; Lasher and Zagon, 1972; Phillipson and Sandler, 1975; Chalazonitis and Fischbach, 1980; Bennet and White, 1981; Thangnipon et al., 1983; Kingsbury et al., 1985; Hockberger et al., 1987a; Gallo et al., 1987). In several instances, the beneficial effects were shown to be most dramatic during the first week in culture. Although it is not known how elevated potassium prolongs neuronal survival, it seems reasonable to speculate that its depolarizing effect on membrane potential may be involved. In cultured cerebellar granule cells, TTX did not prevent the beneficial effects of high potassium, indicating that, at least in those cells, activation of voltage-dependent sodium channels was not necessary (Gallo et al., 1987). On the other hand, agents that reduced $\mathrm{Ca}^{2+}$ influx or inhibited calmodulin blocked the effects of high potassium, suggesting that elevation of intracellular $\mathrm{Ca}^{2+}$ may be important in granule cell survival (Gallo et al., 1987). It will be interesting to see whether this observation holds true for other cell types.

In addition to high potassium, we found that the stage at which the PCs were dissociated was also a critical factor in cell survival and differentiation. This observation supports those of Fields et al. (1982) and Weber and Schachner (1984), who showed that postnatal PCs did not survive as well in culture as embryonic PCs. By attempting to grow cells at each stage between embryonic day 20 and postnatal day 14 , we determined more exactly that PCs would not differentiate in culture if dissociated after postnatal day 2 even if high potassium was present. PCs in stage 2 of development (P1-P4) are just beginning to differentiate, and synaptic contact with climbing fibers begins. Attempts at supplementing the medium with either glutamate or aspartate, instead of high potassium, was not beneficial to cells. This suggests that withdrawal from these neurotransmitters was probably not the reason for the poor survival of postnatal PCs, and it further indicates that depolarization alone was not sufficient for cell differentiation. Clearly, there is still much to be learned about the conditions that foster cell survival and differentiation in culture.

Finally, we observed that some of the properties expressed in acutely isolated PCs were also present in cultured PCs. In particular, embryonic PCs cultured for several weeks displayed action potentials, glutamate responses, and voltage-dependent conductances similar to PCs isolated in stage 4 of development. However, unlike the isolated cells, the culturcd PCs displayed action potential waveforms reminiscent of climbing fiber-like responses in vivo. This suggests that such waveforms may be generated in the dendrites. In the following article (Hockberger et al., 1989), we show that cultured PCs also displayed dendritic compartmentalization of their $\mathrm{Ca}$ responses, a feature of PCs in cerebellar slices. Taken together, our results indicate that several aspects of the PC differentiation can develop in the absence of the highly structured organization of the intact cerebellum (also see Woodward et al., 1974, 1975; Mariani et al., 1977).

\section{References}

Addison, W. (1911) The development of the Purkinje cells and of the cortical layers in the cerebellum of the albino rat. J. Comp. Neurol. 21: 459-487.

Allerand, C. (1971) Patterns of neuronal differentiation in developing cultures of neonatal mouse cerebellum: $A$ living and silver impregnation study. J. Comp. Neurol. 142: 167-204.

Altman, J. (1972) Postnatal development of the cerebellar cortex in 
the rat. II. Phases in the maturation of Purkinje cells and of the molecular layer. J. Comp. Neurol. 145: 399-464.

Altman, J. (1982) Morphological development of the rat cerebellum and some of its mechanisms. Exp. Brain Res. (Suppl.) 6: 8-46.

Altman, J., and W. Anderson (1972) Experimental reorganization of the cerebellar cortex. I. Morphological effects of elimination of all microneurons with prolonger X-irradiation started at birth. J. Comp. Neurol. 146: 355-406.

Altman, J., and S. Bayer (1985) Embryonic development of the rat cerebellum. I. Delineation of the cerebellar primordium and early cell movements. J. Comp. Neurol. 231: 1-26.

Altman, J., and A. Winfree (1977) Postnatal development of the cerebellar cortex in the rat. V. Spatial organization of Purkinje cell perikarya. J. Comp. Neurol. 171: 1-16.

Barclay, A. (1979) Localization of the Thy-1 antigen in the cerebellar cortex of rat brain by immunofluorescence during postnatal development. J. Neurochem. 32: 1249-1257.

Bennett, M. R., and W. White (1981) The survival and development of cholinergic neurons in potassium-enriched media. Brain Res. 173: 549-553.

Berry, M., and P. Bradley (1976) The growth of the dendritic trees of Purkinje cells in irradiated agranular cerebellar cortex. Brain Res. 116: 361-387.

Bornstein, M., and M. Murray (1958) Serial observations on patterns of growth, myelin formation, maintenance and degeneration in cultures of new-born rat and kitten cerebellum. J. Biophys. Biochem. Cytol. 4: 499-504.

Calvet, M. (1974) Patterns of spontaneous electrical activity in tissue cultures of mammalian cerebral cortex vs cerebellum. Brain Res. 69 : 281-289.

Chalazonitis. A., and G. Fischbach (1980) Elevated potassium induces morphological differentiation of dorsal root ganglionic neurones in dissociated cell culture. Dev. Biol. 78: 173-183.

Connor, J. A. (1986) Digital imaging of free calcium changes and of spatial gradients in growing processes in single, mammalian central nervous system cells. Proc. Natl. Acad. Sci. USA 83: 6179-6183.

Connor, J. A., H. Tseng, and P. Hockberger (1987) Depolarization and transmitter induced changes in intracellular $\mathrm{Ca}^{2+}$ of rat cerebellar granule cells in explant cultures. J. Neurosci. 7: 1384-1400.

Crepel, F. (1971) Maturation of climbing fibre response in the rat. Brain Res. 35: 272-276.

Crepel, F. (1972) Maturation of the cerebellar Purkinje cells. I. Postnatal evaluation of the Purkinje cell spontaneous firing in the rat. Exp. Brain Res. 14: 463-471.

Crepel, F., J. Mariani, and N. Delhaye-Bouchaud (1976) Evidence for a multiple innervation of Purkinje cells by climbing fibers in the immature rat cerebellum. J. Neurobiol. 7: 567-578.

Crepel, F, N. Delhaye-Bouchaud, and J. Dupont (1981) Fate of the multiple innervation of the cerebellar Purkinje cells by climbing fibers in immature controls, X-irradiated and hypothyroid rats. Dev. Brain Res. 1: 59-71.

Fields, K., D. Currie, and G. Dutton (1982) Development of Thy-1 antigen on cerebellar neurons in culture. J. Neurosci. 2: 663-673.

Gahwiler, B. (1976) Spontaneous bioelectric activity of cultured Purkinje cells during exposure to glutamate, glycine and strychnine. J. Neurobiol. 7: 97-107.

Gahwiler, B., A. Mamoon, and C. Tobias (1973) Spontaneous bioelectric activity of cultured cerebellar Purkinje cells during exposure to agents which prevent synaptic transmission. Brain Res. 53:71-79.

Gallo, V., A. Kingsbury, R. Balazs, and O. Jorgensen (1987) The role of depolarization in the survival and differentiation of cerebellar granule cells in culture. J. Neurosci. 7: 2203-2213.

Garson, J., P. Beverley, H. Coakham, and E. Harper (1982) Monoclonal antibodies against human $T$ lymphocytes label Purkinje neurones of many species. Nature 298: 375-377.

Geller, H., and D. Woodward (1974) Responses of cultured cerebellar neurons to iontophoretically applied amino acids. Brain Res. 74:6780.

Gruol, D. (1983) Cultured cerebellar neurons: Endogenous and exogenous components of Purkinje cell activity and membrane response to putative transmitters. Brain Res. 263: 223-241.

Gruol, D., and C. Franklin (1987) Morphological and physiological differentiation of Purkinje neurons in cultures of rat cerebellum. $\mathbf{J}$. Neurosci. 7: 1271-1293.
Hamill, O., A. Marty, E. Neher, B. Sakmann, and F. Sigworth (1981) Improved patch-clamp techniques for high-resolution current recording from cells and cell-free membrane patches. Pfluegers Arch. 391: 85-100.

Hendelman, W., and A. Aggerwal (1980) The Purkinje neuron: I. A Golgi study of its development in the mouse and in culture. J. Comp. Neurol. 193: 1063-1079

Hild, W., and I. Tasaki (1962) Morphological and physiological properties of neurons and glial cells in tissue culture. J. Neurophysiol. 25: 277-304.

Hillman, D., and S. Chen (1981) Vulnerability of cerebellar development in malnutrition. II. Intrinsic determination of total synaptic area on Purkinje cell spines. Neuroscience 6: 1263-1275.

Hirano, A., and H. Dembitzer (1973) Cerebellar alterations in the weaver mouse. J. Cell Biol. 56: 478-486.

Hirano, T., and H. Ohmori (1986) Voltage-gated and synaptic currents in rat Purkinje cells in dissociated cultures. Proc. Natl. Acad. Sci. USA 83: 1945-1949.

Hockberger, P., H. Tseng, and J. A. Connor (1987a) Immunocytochemical and electrophysiological differentiation of rat cerebellar granule cells in explant cultures. J. Neurosci. 7: 1370-1383.

Hockberger, P., H. Tseng, and J. A. Connor (1987b) Electrophysiological properties of cerebellar Purkinje cells after dissociation from late embryonic and early postnatal rats. Soc. Neurosci. Abstr. 13: 1119.

Hockberger, P., H. Tseng, and J. A. Connor (1989) Fura-2 measurements of cultured rat Purkinje neurons show dendritic localization of $\mathrm{Ca}^{2+}$ influx. J. Neurosci. 9: 2272-2284.

Ito, M. (1984) The Cerebellum and Neural Control, Raven, New York. Kingsbury, A., V. Gallo, P. Woodhams, and R. Balazs (1985) Survival, morphology and adhesion properties of cerebellar interneurons cultured in chemically defined and serum supplemented medium. Brain Res. 17: 17-25.

Lasher, R., and I. Zagon (1972) The effect of potassium on neuronal differentiation in cultures of dissociated newborn rat cerebellum. Brain Res. 41: 482-488.

Leiman, A., and F. Seil (1973) Spontaneous and evoked bioelectric activity in organized cerebellar tissue cultures. Exp. Neurol. 40: 748758.

Llinás, R., ed. (1969) Neurobiology and Cerebellar Evolution and Development, American Medical Assoc. Chicago, IL.

Llinás, R., and M. Sugimori (1980a) Electrophysiological properties of in vitro Purkinje cell soma in mammalian cerebellar tissue. J. Physiol (Lond.) 305: 171-195.

Llinás, R., and M. Sugimori (1980b) Electrophysiological properties of in vitro Purkinje cell dendrites in mammalian cerebellar tissue. J. Physiol. (Lond.) 305: 197-213.

Lohmann, S., U. Walter, P. Miller, P. Greengard, and P. DeCamilli (1981) Immunohistochemical localization of cyclic GMP-dependent protein kinase in mammalian brain. Proc. Natl. Acad. Sci. USA 78 653-657.

Mariani, J., F. Crepel, K. Mikoshiba, J.-P. Changeux, and C. Sotelo (1977) Anatomical, physiological and biochemical studies of the cerebellum from reeler mutant mouse. Phil. Trans. R. Soc. London 281: 1-28.

Marshall, K., J. Wojotwicz, and W. Hendelman (1980) Patterns of functional synaptic connections in organized cultures of cerebellum. Neuroscience 5: 1847-1857.

Messer, A., G. Snodgrass, and P. Maskin (1984) Enhanced survival of cultured Purkinje cells by plating on antibody to Thy-1. Cell. Mol. Neurobiol. 4: 285-290.

Moonen, G., E. Neale, R. MacDonald, W. Gibbs, and P. Nelson (1982) Cerebellar macroneurons in microexplant cell culture. Methodology, basic electrophysiology, and morphology after horseradish peroxidase injection. Dev. Brain Res. 5: 59-73.

Morris, R., J. Beech, P. Barber, and G. Raisman (1985) Early stages of Purkinje cell maturation demonstrated by Thy-1 immunohistochemistry on postnatal rat cerebellum. J. Neurocytol. 14:427-452.

Mugnaini, E., A. Berrebi, A. Dahl, and J. Morgan (1988) The polypeptide PEP-19 is a marker for Purkinje neurons in cerebellar cortex and cartwheel neurons in the dorsal cochlear nucleus. Arch. Ital. Biol. 126: 41-67.

Nelson, P., and J. Peacock (1973) Electrical activity in dissociated cell cultures from fetal mouse cerebellum. Brain Res. 61: 163-164. 
Novelli, A., and R. Henneberry (1987) cGMP synthesis in cultured cerebellar neurons is stimulated by glutamate via a $\mathrm{Ca}^{2+}$-mediated, differentiation-dependent mechanism. Dev. Brain Res. 34: 307-310.

Phillipson, D., and M. Sandler (1975) The influence of nerve growth factor, potassium depolarization and dibutyryl(cyclic)adenosine $3^{\prime}, 5^{\prime}$ monophosphate on explant cultures of chick embryo sympathetic ganglia. Brain Res. 90: 273-281.

Purkinje, J. (1838) Versammlung der Naturforscher und Aertze zur Prag. Isis von Oken 7:581.

Rakic, P., and R. Sidman (1973) Organization of cerebellar cortex secondary to deficit of granule cells in weaver mutant mice. J. Comp. Neurol. 152: 133-162.

Ramón y Cajal, S. (1890) Sur les fibres nerveuses de le couche granuleuse de cervelet sur l'evolution des elements cerebelleux. Int. Monatsschrift Anat. Phys. 7: 12-31.

Regan, L. (1987) Calcium channels in freshly-dissociated rat cerebellar Purkinje cells. Soc. Neurosci. Abstr. 13: 100.

Rogawski, M. (1985) The A-current: How ubiquitous a feature of excitable cells? Trends Neurosci. 8: 214-219.

Romijn, H., A. Habets, M. Mud, and P. Walters (1982) Nerve outgrowth, synaptogenesis and bioelectric activity in fetal rat cerebral cortex tissue cultured in serum-free, chemically defined medium. Dev. Brain Res. 2: 583-589.

Schmechel, D., M. Brightman, and P. Marangos (1980) Neurons switch from non-neuronal enolase to neuron-specific enolase during differentiation. Brain Res. 190: 195-214.

Scott, B. (1971) Effect of potassium on neuron survival in cultures of dissociated human nervous tissue. Exp. Neurol. 30: 297-308.

Scott, B. (1977) The effect of elevated potassium on the time course of neuron cell survival in cultures of dissociated dorsal root ganglia. J. Cell Physiol. 91: 305-316.

Scott, B., and K. Fisher (1970) Potassium concentration and number of neurons in cultures of dissociated ganglia. Exp. Neurol. 27: 16-22.

Seil, F. (1972) Neuronal groups and fiber patterns in cerebellar tissue cultures. Brain Res. 42: 33-51.

Shimono, T., S. Nosaka, and K. Sasaki (1976) Electrophysiological study on the postnatal development of neuronal mechanisms in the rat cerebellar cortex. Brain Res. 108: 279-294.

Siggins, G., S. Hendricksen, and S. Landis (1976) Electrophysiology of Purkinje neurons in the weaver mouse: Iontophoresis of neuro- transmitters and cyclic nucleotides, and stimulation of the nucleus locus cocrulcus. Brain Res. 114: 53-69.

Snider, R., S. Teramoto, and J. Ban (1967) Activity of Purkinje and basket cells in chronically isolated cerebellar folia. Exp. Neurol. 19: 443-454.

Sotelo, C. (1975) Anatomical, physiological and biochemical studies on the cerebellum from mutant mice: II. Morphological study of cerebellar cortical neurons and circuits in the weaver mouse. Brain Res. 94: 19-44.

Tabuchi, K., W. Kirsch, and P. Nakane (1976) The fine structural localization of S-100 protein in rodent cerebellum. J. Neurol. Sci. 28: $65-76$.

Thangnipon, W., A. Kingsbury, M. Webb, and R. Balazs (1983) Observations on rat cerebellar cells in vitro: Influence of substratum, potassium concentration and relationship between neurones and astrocytes. Dev. Brain Res. 11: 177-189.

Waddington, G., and P. Banks (1981) The development of pre- and postsynaptic components of the noradrenergic system in the rat cerebellum. Dev. Brain Res. 11: 177-189.

Weber, A., and M. Schachner (1984) Maintenance of immunologically identified Purkinje cells from mouse cerebellum in monolayer culture. Brain Res. 311: 119-130.

Wolf, M. (1964) Differentiation of neuronal types and synapses in myelinating cultures of mouse cerebellum. J. Cell Biol. 22: 259-279.

Wolf, M. (1970) Anatomy of cultured mouse cerebellum. II. Organotypic migration of granule cells demonstrated by silver impregnation of normal and mutant cultures. J. Comp. Neurol. 140: 281-297.

Woodward, D., B. Hoffer, and L. Lapham (1969) Development of electrical and enzyme histochemical activity in Purkinje cells. Exp. Neurol. 23: 120-139.

Woodward, D., B. Hoffer, G. Siggins, and F. Bloom (1971) The ontogenetic development of synaptic junctions, synaptic activation and responsiveness to neurotransmitter substances in rat cerebellar Purkinje cells. Brain Res. 34: 73-97.

Woodward, D., B. Hoffer, and J. Altman (1974) Physiological and pharmacological properties of Purkinje cells in rat cerebellum degranulated by postnatal X-irradiation. J. Neurobiol. 5: 283-304.

Woodward, D., D. Bickett, and R. Chanda (1975) Purkinje cell dendritic alterations after transient developmental injury of the external granular layer. Brain Res. 97: 195-214. 